\title{
Severe chorea after acute carbon monoxide poisoning
}

\author{
P DAVOUS, P RONDOT, MH MARION, B GUEGUEN \\ From the Department of Neurology, Cochin Port-Royal School of Medicine, Paris, France
}

SUMMARY Ten days after an acute exposure to carbon monoxide, a 33-year-old woman exhibited severe chorea. CT scan revealed bilateral lucencies of the pallidum and anterior arm of the internal capsule. Chorea was successfully treated by chlorpromazine and did not relapse aftee treatment withdrawal. The mechanism of chorea in acute carbon monoxide poisoning is discussed:-

Chorea is not a classical feature of carbon monoxide poisoning. In his 1968 review of carbon monoxide poisoning, Jellinger ${ }^{1}$ was able to collect only eight references describing choreiform movements or choreoathetosis. Of 2360 acutely intoxicated patients reported by Choi, ${ }^{2} 65$ exhibited delayed neurologic sequellae but chorea was not observed. To our knowledge, the pathological lesion corresponding to these abnormal movements in carbon monoxide poisoning is not known.

\section{Case report}

A 33-year-old woman was referred to our neurological department for treatment of abnormal movements. She had been previously in good health, without psychiatric illness and she was not taking any medication. In August 1983, she was found unconscious after exposure to a combustion heater in a closed bathroom in Morocco. Her child was found dead. She was taken to a nearby hospital and awoke some hours after discovery. On the second hospital day, she complained of imbalance and dysarthria but was discharged. The fifth day after carbon monoxide exposure, she was referred to another hospital with intention tremor and ataxia but she was not admitted. Abnormal movements appeared ten days after poisoning.

On admission, 12 days after carbon monoxide exposure, temperature was $36,8^{\circ} \mathrm{C}$, blood pressure $150 / 90 \mathrm{~mm} \mathrm{Hg}$, respiration 24 per minute. The patient was fully conscious. She was severely dysarthric and swallowing was impaired. General examination revealed no abnormalities. Neurological examination revealed a normal mental status. Abnormal involuntary movements were extremely violent. They were brisk, arhythmic and of great amplitude. They involved the trunk, the neck, the four limbs and spared the

Address for reprint requests: P Davous, Hôpital Sainte Anne, 1 Rue Cabanis, 75674 Paris Cedex 14 France.

Received 5 March 1985 and in revised form 2 July 1985. Accepted 6 July 1985 face. They consisted of flexion-extension of the distal mus̆ cles of the legs and of the forearms. The proximal muscles the legs were involved in a rotational movement. The trun was arhythmically pushed forward and the head was moving from side to side. Attitude fixing, stress and movements induced bursts of choreic movements. More distally, thies hands were involved by choreoathetoid movements. This patient could not stand up or walk. There was diffuse hyoo tonia and normal strength of all muscles. Coordination 4 se ing was disturbed by abnormal movements. Deep ten केon. reflexes were mildly exaggerated on the left side but there was no Babinski sign. The sensory system was nornfaf Vision, eye movements, pupils reaction to light appefife normal.

The results of routine admission blood studies were mal. A polygraphic surface electromyogram recorded the activity of the right biceps and triceps, extensor and flexof muscles of the right wrist, right sternomastoid and left splenius, right tibialis anterior and soleus muscles. It showed $\Phi$ spontaneous arhythmic activity (fig 1) made of short burs 1 to $5 \mathrm{~s}$ duration and 100 to $600 \mathrm{mV}$ amplitude. Occasionally a simultaneous burst occurred in two antagonistic muscles Tonic activity was observed in the wrist extensors and in the tibialis anterior. The frequency and amplitude of the arhythmic movements were exaggerated by mental arith metic or sensory stimulation.

CT scan without contrast material (fig 2) showed bilatera areas of lucency close to pallidum and anterior limb of the. internal capsules. The patient was given chlorpromazine $150 \mathrm{mg}$ daily and maintained two days on supportive care with nasogastric intubation. She improved dramatically over the next few days and was able to stand, walk and take fluids by mouth on the fifth day after admission. Abnorma movements were limited to rare bursts of the trunkal muso culature and athetoid movements of the hands. The speeck was very slow and dysarthric. Neurological examinatio demonstrated cerebellar dysmetria on the left side. Chlor promazine was progressively reduced and stopped two months after admission.

The follow-up visit 3 months after initial exposure to carer bon monoxide showed no personality change and neuro 


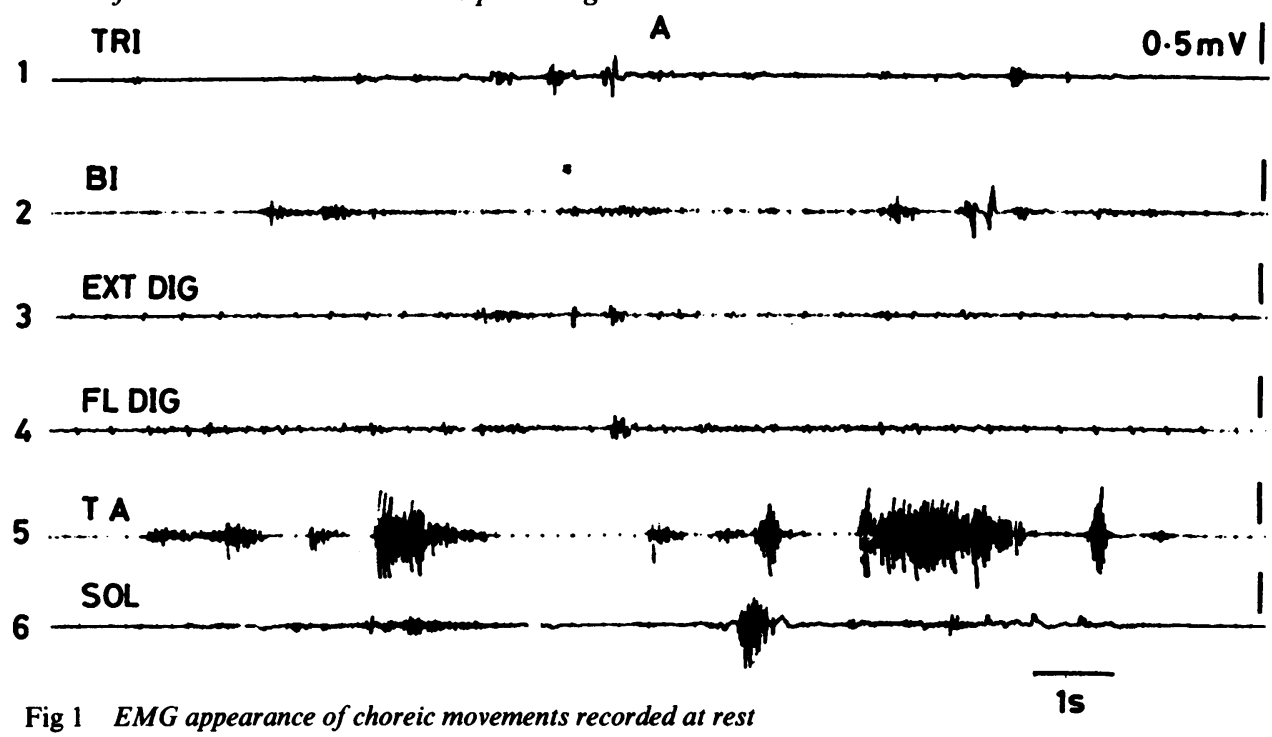

psychologic assessment of cognitive functions was within normal limits. The patient had a slow dysarthric speech but she could sing with melody. Choreoathetosic movements were very rare and only initiated by emotions or attitude. Except for mild incoordination and hypotonia on the left side, the neurological examination was normal.

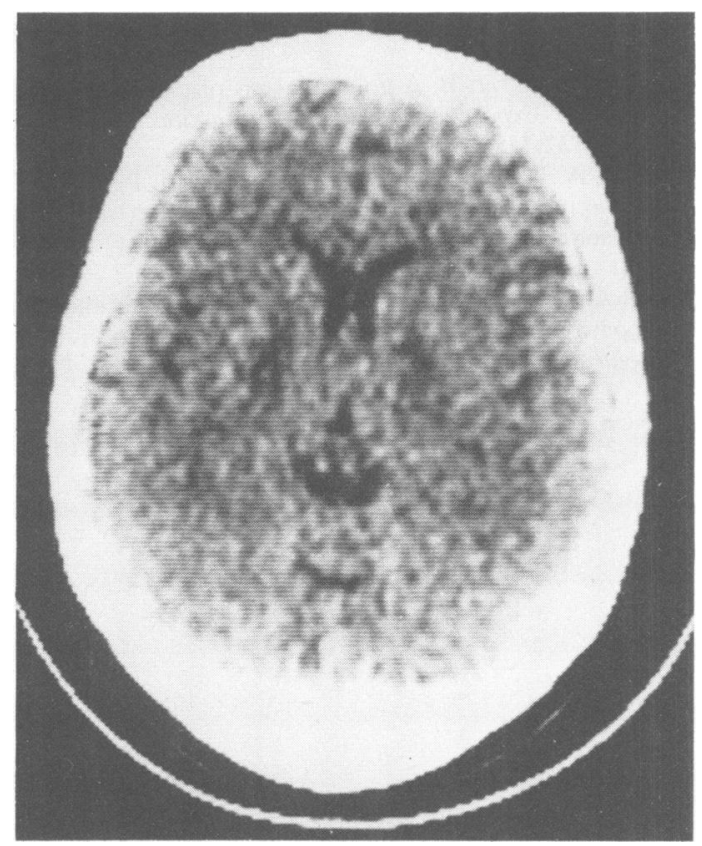

Fig 2 Unenhanced computed tomographic scan two weeks after acute carbon monoxide intoxication demonstrating lucencies in both basal ganglia.

\section{Discussion}

The anatomical basis for abnormal movements in carbon monoxide poisoning is not known. In a recent paper, Schwartz et al ${ }^{3}$ reported a case of choreoathetosis with infarction of the neostriatum on CT scan, suggesting a relationship between this structure and the abnormal movements. Nevertheless, a similar lesion was observed on the right side by Delouvrier $\boldsymbol{e t}$ $a l^{4}$ without chorea. Low density areas seen on CT scan of our patient did not involve the caudate or the putamen nuclei. To our knowledge, the only report of chorea following carbon monoxide poisoning which was anatomically verified was by Merguet. ${ }^{5}$ There was no remarkable involvement of the basal ganglia but some glial proliferation and granular cells in these structures. In addition, patients affected by chorea of vascular origin were rarely demonstrated to have significant lesions in their basal ganglia. ${ }^{67}$ Conversely, the most frequent lesion of the basal ganglia observed after carbon monoxide poisoning, the necrosis of both pallida, is not followed by chorea but by hypertonic features, Parkinsonian state or dystonia. ${ }^{18-14}$

Thus, it is likely that chorea observed in our case was not related to the pallidal lucencies observed on CT scan but was attributable to some lesion in the vicinity of the internal pallidum, either the subthalmic region or the adjacent internal capsule. Of the rare cases of chorea following carbon monoxide poisoning, some of them were transient, ${ }^{381516}$ others had a chronic course. ${ }^{517}$ In our case, the fact that chorea did not relapse after neuroleptic arrest could suggest a functional rather than an anatomical impairment. The pathophysiological pattern of the 
choreic syndrome was probably excessive dopaminergic output on the receptors of the striatum since chorea was alleviated by neuroleptics. A tentative explanation of the abnormal movements could be related to neuronal plasticity, as suggested by hyperactivity and delayed spine development of caudate neurons observed after carbon monoxide exposure in the rat. ${ }^{1819}$ The chorea observed in our case could be the result of deafferentation of the striatum and increase output until compensatory inhibition of abnormal activity. Such an interpretation could explain the latency of such sequellae and spontaneous improvement. Whether this could be related to the delay in appearance of CT changes and to their disappearance, as suggested previously, ${ }^{2021}$ is still debatable.

\section{References}

${ }^{1}$ Jellinger $\mathrm{K}$. Degenerations and exogenous lesions of the pallidum and striatum. In: Vinken PJ, Bruyn GW, eds. Handbook of Clinical Neurology, Vol 6. Amsterdam: North Holland Publishing Co, 1968.

${ }^{2}$ Choi IS. Delayed neurologic sequellae in carbon monoxide intoxication Arch Neurol 1983;40:433-5.

${ }^{3}$ Schwartz A, Hennerici M, Wegener OH. Delayed choreoathetosis following acute carbon monoxide poisoning. Neurology (Cleveland) 1985;35:98-9.

${ }^{4}$ Delouvrier JJ, Tritschler JL, Dehen H. Aspect tomodensitométrique d'une intoxication oxycarbonée. Nouv Presse Med 1979;8:3830.

${ }^{5}$ Merguet $\mathbf{H}$. Ein fall von Kohlenoxydvergiftung mit choreiformer Bewegungsstörung. Arch Psychiat 1922;66: 272-82.

${ }^{6}$ Bruyn GW, Padberg G. Chorea and systemic lupus erythematosus. Eur Neurol 1984;23:278-90.

${ }^{7}$ Saris S. Chorea caused by caudate infarction. Arch Neurol 1983;40:590-1.

${ }^{8}$ Desoille H. Les troubles nerveux dus aux asphyxies aiguës (et plus spécialement à l'asphyxie oxycarbonée) Thesis Paris, Le François Ed. 1932.
${ }^{9}$ Lapresle J, Fardeau M. The central nervous system and으 carbon monoxide poisoning. II Anatomical study of $Z$ brain lesions following intoxication with carbon mon- $\mathbb{D}$ oxide. Prog Brain Res 1967;24:31-74.

${ }^{10}$ Sills JA, Vivori E, Rosenbloom L. Carbon monoxide poisoning: recovery associated with a transient dyskinetie syndrome. Postgrad Med J 1974;50:519-20.

${ }^{11}$ Franke A, Neu I. Ein fall von Torsions-Dystonie nach Kohlenmonoxyd-vergiftung. Nervenarzt 1977;48: 345-7.

${ }^{12}$ Sawada Y, Takahashi M, Ohashi N, et al. Computerised tomography as an indication of long-term outcome after acute carbon monoxide poisoning. Lancet $\stackrel{\overrightarrow{+}}{+}$ 1980;1:783-4.

${ }^{13}$ Klawans HL, Stein RW, Tanner CM, Goetz CG. A pure $\frac{\bar{C}}{\overline{0}}$ Parkinsonian syndrome following acute carbon monox- $\overline{\bar{c}}$ ide intoxication. Arch Neurol 1982;39:302-4.

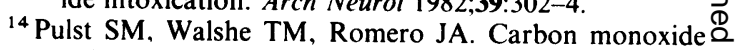
poisoning with features of Gilles de la Tourette's syndrome. Arch Neurol 1983;40:443-4.

${ }^{15} \mathrm{Janz}$ HW. Über den Aufbau und die Enstehungs- $\vec{\circ}$ bedingungen cerebraler Krankheitsbilder nach Kohl- $\overrightarrow{\vec{\omega}}$ enoxydvergiftung. Arch Psychiatry 1942;114:539-93.

${ }^{16}$ Stengel E, Zellermayer J. Zur kenntnis der Hyperkinesen nach Leuchtgasvergiftung. Monatsschr Psychiat 1937; 95:213-32.

${ }^{17}$ Dereux J, Catoir J. Deux complications nerveuses partic- $\vec{c}$ ulières de l'intoxication par l'oxyde de carbone $N$ syndrome parkinsonien transitoire avec inertie Et mutisme et chorée chronique. Rev Neurol (Pari 1952;86:40-3.

${ }^{18}$ Culver B, Norton S. Juvenile hyperactivity in rats after acute exposure to carbon monoxide. Exp Neu@ T 1976;50:80-98

${ }^{19}$ Norton S, Culver B. A golgi analysis of caudate neurof in rats exposed to carbon monoxide. Brain $R$ 1977;132:455-65.

${ }^{20}$ Destee A, Courteville V, Devos Ph, Besson P, Warot $\stackrel{2}{P_{0}}$ Computed tomography and acute carbon monoxide के poisoning. J Neurol Neurosurg Psychiatry 1985;48: 281-2.

${ }^{21}$ Sawa GM, Watson CPN, Terbrugge K. Delayed encephalopathy following carbon monoxide intoxication. Can $J$ Neurol Sci 1981;8:77-9. 